\title{
Adaptive ability, stability and pliability of lettuce in changeable ecological conditions
}

Khareba O. ${ }^{1}$, Gorova T. ${ }^{2}$

Institute of Vegetable growing and Melon Growing NAAS, Instytutska Str., 1, Selectsiine, Kharkiv region, Kharkiv oblast, 62478, Ukraine; e-mail: 1, 20voch.iob@gmail.com

The purpose. To determine systems of interaction grade - medium - yield with the use of calculus, simulation and prediction on an instance of dependence of productivity of lettuce of grade Snizhynka on hydrothermal quotients of zones of Left-bank Forest-steppe and Polissia. Methods. Field, laboratory, statistical. Results. It was fixed that best values of hydrothermal quotient (HTQ) for deriving maximum level of productivity in conditions of Left-bank Forest-steppe made $0,8-1$, and in conditions of Polissia - 1,2-2. In conditions of Polissia influence of weather environment on productivity of lettuce was the least. Relative stability of grade was higher in conditions of Foreststeppe $(20,24 \%)$. But in conditions of Forest-steppe on parameter bi lettuce of grade Snizhynka was more ecologically plastic $(1,24)$, that is at favorable weather environment it showed rather high productivity. In conditions of Polissia, on the contrary, grade Snizhynka was less plastic $(0,76)$ and with a smaller level of relative stability of genotype $(15,94 \%)$. Selection worth of genotype (SWG) for lettuce of grade Snizhynka in zone of Polissia made 4,59. Conclusions. In zone of Left-bank Forest-steppe according to the year of growing at oscillation of the sum of active temperatures within the limits of $1076-1318^{\circ} \mathrm{C}$ and oscillation of sum of rainfalls of $56,6-193,6 \mathrm{~mm}$ the productivity of lettuce of grade Snizhynka made $6,7-12,2 \mathrm{t} /$ hectare. In zone of Polissia the ratio of rainfall to sum of active temperatures (HTQ) almost did not influence formation of productivity at its oscillation within the limits of $0,65-1,48$. Dependence of formation of productivity in zones of Forest-steppe and Polissia on quotient of elasticity made 0,05 and 0,26 , that specified favorable conditions of native zone of Left-bank Forest-steppe for growing lettuce. General and specific adaptive abilities of grade Snizhynka were above in zone of Foreststeppe (0,75 and 3,93 accordingly), the best selection worth of genotype of grade was characteristic for zone of Polissia $(4,59)$.

Key words: lettuce, grade, hydrothermal quotient, adaptive ability, genotype, phenotype, variability, pliability, productivity.

https://doi.org/10.31073/agrovisnyk201901-04

Introduction. For agricultural production it is important to find stable varieties of vegetable crops for cultivation in different soil-climatic conditions of Ukraine [1,2]. Sown lettuce is a valuable vegetable crop, the yield and especially the quality of which greatly depends on the conditions of cultivation [3-5]. It should be noted that no scientific development of domestic scientists includes the study of the parameters of zonal variability of the yield of the lettuce depending on the meteorological conditions of the cultivation [6].

According to the biological characteristics of the salad, the plant is cold-resistant, a long day crop, demanding to the illumination and moisture of the soil and air, since it has a large evaporation of the leaves [7]. Young plants withstand a decrease in temperature to $1 \ldots 2^{\circ} \mathrm{C}$ and short-term frosts to $-6-8$ ${ }^{\circ} \mathrm{C}$. The optimum temperature for growth and development of lettuce is $15-20{ }^{\circ} \mathrm{C}$. Soils acidity with a reaction close to neutral $\mathrm{pH}$ of 6.0-6.8 are optimal for cultivating the lettuce. Plant grows well on structural, fertile, sandy loamy, flood-rich soils with high content of humus [1, 2].

Analysis of recent research and publications. As noted in the numerous studies of Ukrainian scientists (RL Borisov, MF Peregudt [3], MF Grushko [4,5], TK Horovaia [1, 6], O. Zavadskaya [7] , O. Poznyak, Yu. V. Tkalych [8], Z. D. Sich [9], O. I. Ulyanych [2]) is economically advantageous to grow a 
salad (Lactuca sativa L.) in the presence of high-yielding varieties resistant to pathogens and stinging, shaded and heat-resistant, environmentally-friendly and stable in terms of yield and quality of marketable products. The typical representative of the leaf variety of the sown lettuce is the 'Snizhynka' variety, which is included in the State Register of Plant Varieties, suitable for distribution in Ukraine

The purpose of research. To determine the dependence of the yield of lettuce of the seedlings' snowflake 'Snizhynka' on the hydrothermal coefficients of the zones of the Left Bank Forest-steppe and Polissya, to analyze the parameters of the zone's adaptability of the variety.

Materials and methods, and conditions for conducting research. The research was carried out during 2006-2015 according to the Methodology of the Experimental Case in Vegetable and Melons (2001) [10] under the conditions of the Left Bank Forest-Steppe (Institute of Vegetable and Melon Growing, NAAS of Ukraine) and Polissya (experimental station 'Mayak' IOB NAAN) with the Snowflake variety. The technology of growing the salad included seeding early in the spring (second to third decades of April) with a norm of $2.5 \mathrm{~kg} /$ ha to a depth of $1-2 \mathrm{~cm}$ in a tape $(20+50 \mathrm{~cm})$. During the growing season, harrowing was carried out across the lines of the lines, 2 inter-row mechanized work (first to a depth of 6-8 cm, as soon as the lines are designated, the second - after 10-12 days after the first), manual propelling and watering in the phase of forming the socket of the leaves. The yield of lettuce salad was determined by the complete formation of the leaflet socket, which at this time completely changed the color, and the leaves did not increase in size.

Zonal variability was determined by the methods of Kilchevsky and Khotylova [11], the hydrothermal coefficient for Peasantin [12], the coefficient of elasticity behind Gromyko [13]. The plasticity of the variety was determined according to the method of Eberhard-Russel [14]

Research results and their discussion. It was established that in the zone of the Left Bank Forest-steppe during fluctuations of different vegetation periods, the growth of the sum of active temperatures in the range of 1076-1318 $0 \mathrm{C}$ and the amount of precipitation within the limits of 56,6-193,6 $\mathrm{mm}$ yield of salad of the 'Snowflake' variety was 6.7-12.2 $\mathrm{t} / \mathrm{ha}$, that is, it differed almost twice (Fig. 1).

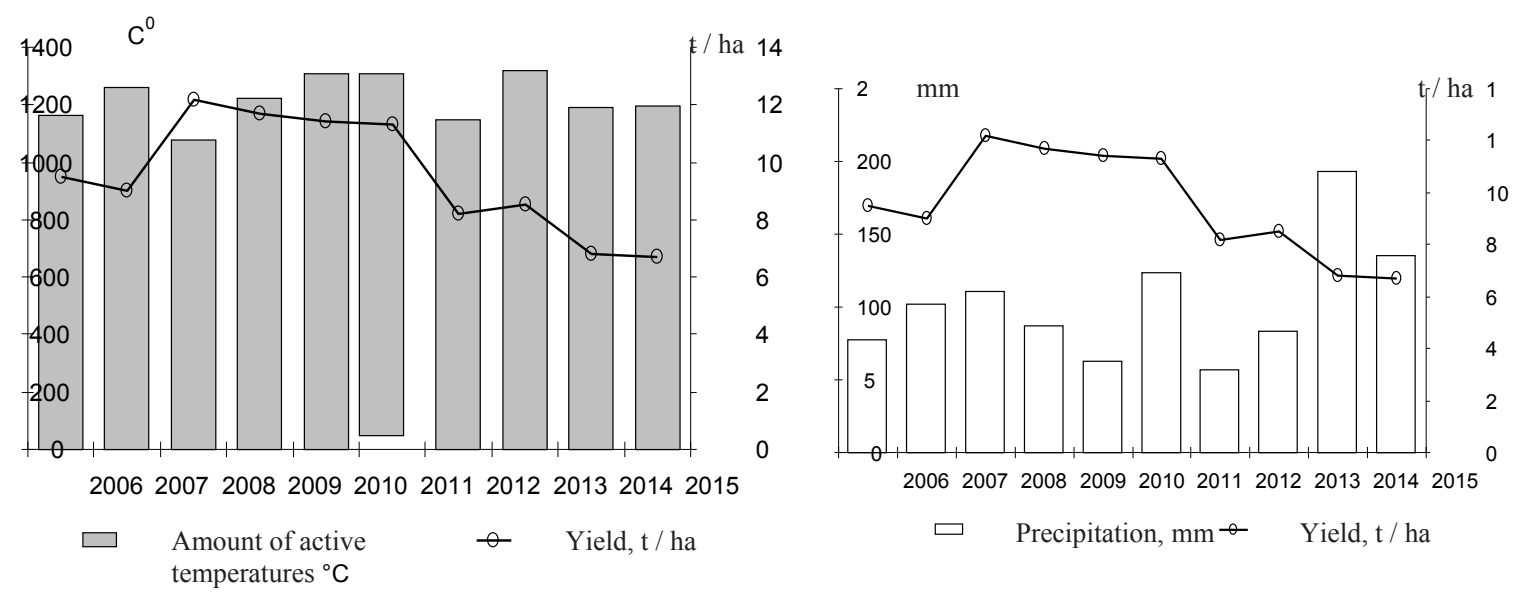

Fig. 1. Variability of yield ( $\mathrm{t} / \mathrm{ha}$ ) of salad of the seedlings 'Snizhynka' in the conditions of the Left Bank Forest-step depending on:

a) the sum of active temperatures $\left({ }^{\circ} \mathrm{C}\right)$, b) the amount of precipitation $(\mathrm{mm})$ (May-June) during growing season

According to the coefficient of variation, it was determined that in the conditions of the Left Bank Forest-steppe Ukraine the amount of active temperatures and hydrothermal coefficient for the vegetation period of the salad varied poorly (coefficient of variation 6.21 and $4.78 \%$ respectively), variability of the parameter of the amount of precipitation was significant (39.2\%), The volatility of the salinity level was average $(21.28 \%)$. It is noted that according to the coefficient of elasticity with an increase in the amount of precipitation by $1 \%$, the yield of salad of the 'Snowflake' varieties for the majority of years grows substantially. The least increase in yields from the increase in precipitation was recorded in 2008 (by 
$0.27 \%$ ) and in 2011 (by $0.23 \%$ ). Also, the optimal values of the SCC were obtained for obtaining the maximum yield in the conditions of the Left-Bank Forest-steppe (Fig. 2). The highest yields of the sown salad were recorded at the level of 0.8 at the hydrothermal coefficient, while the growth rate of the SCC of more than 1.0 indicates a gradual decrease in yield.

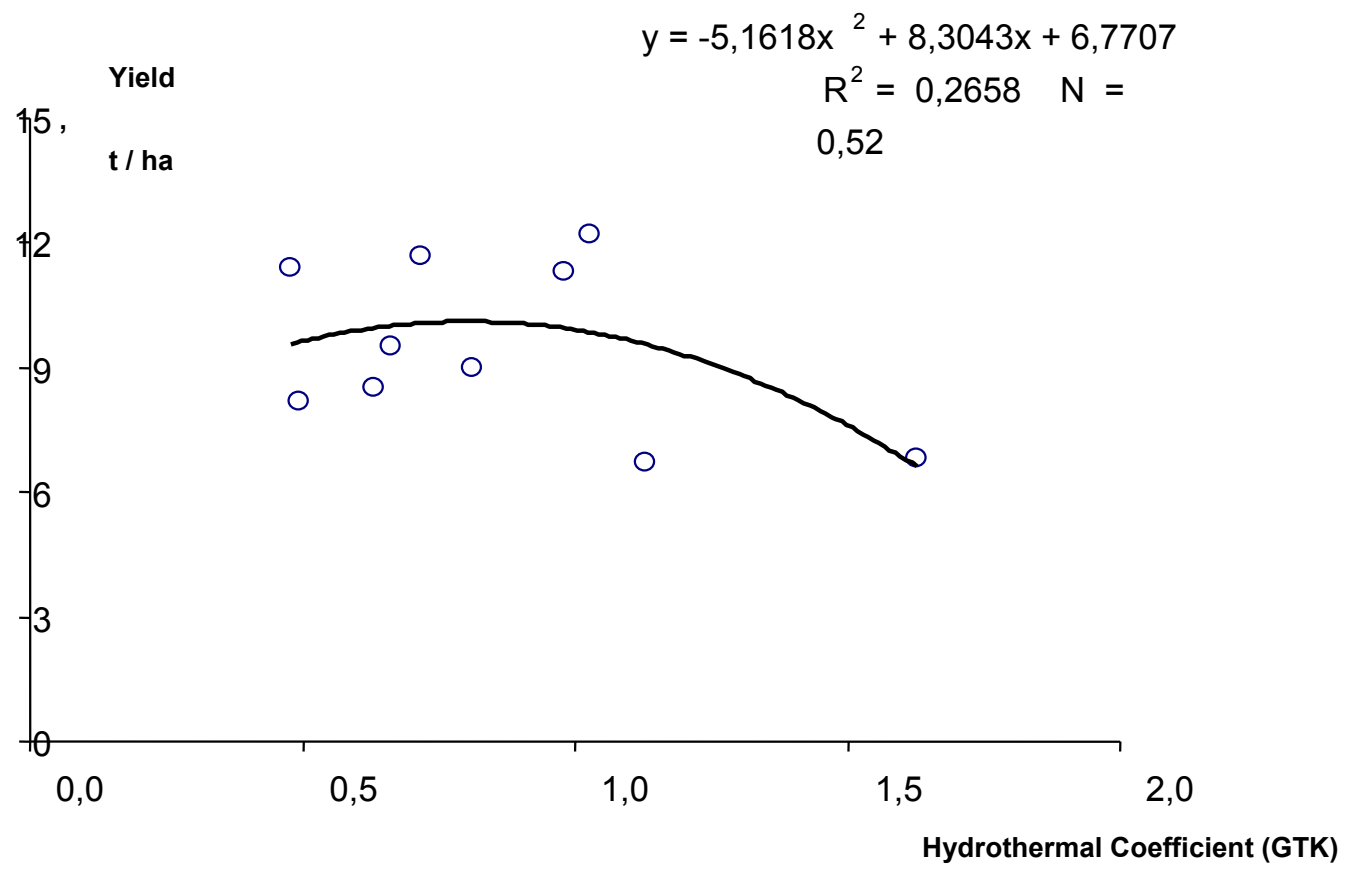

Fig. 2. Dependence of the productivity of the salad of the seedlings 'Snizhynka' on the action of the hydrothermal coefficient for the conditions of the Left Bank Forest-steppe (average for 2006-2015).

An analysis was also carried out of the crop yield of salad for cultivation in the Polissya area (experimental station Mayak) (Figures 3,4). It has been established that this soil-climatic zone causes obtaining a higher level of crop yield. Thus, in 2012, the yield increased to $9.56 \mathrm{t} / \mathrm{ha}$; in 2015 - up to 8.55 $\mathrm{t} / \mathrm{ha}$; in 2006 - to $8.56 \mathrm{t} / \mathrm{ha} ; 2009$ - up to $8.31 \mathrm{t} /$ ha for the sum of active temperatures $1010^{\circ} \mathrm{C}, 1048$, 968 and $1031^{\circ} \mathrm{C}$, and precipitation amounts of $200.1 \mathrm{~mm} ; 167.1 ; 154.8$ and $153.3 \mathrm{~mm}$ respectively. It is noted that at the level of hydrothermal coefficient up to 1.2 the yield of salad in appropriate conditions did not change significantly. As the SCC grows above this threshold, the yield of the crop increases to a level of 9.0-9.5 $\mathrm{t} / \mathrm{ha}$. It was noted that in the conditions of Polissya, the influence of weather conditions on the yield of salad was the lowest, which is confirmed not by high values of the coefficient of elasticity (0.00053-0.00155).
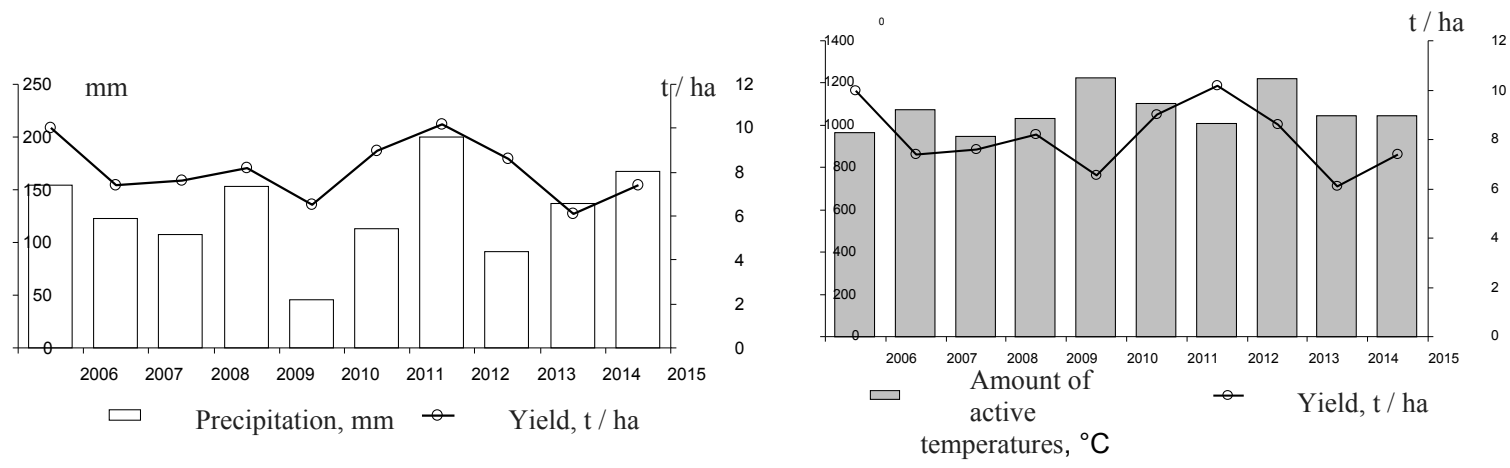

Fig. 3. The variability of the yield of the salad of the seedlings 'Snowflake' in the Polissya area (2006-2015) 


\section{hydrothermal coefficient}

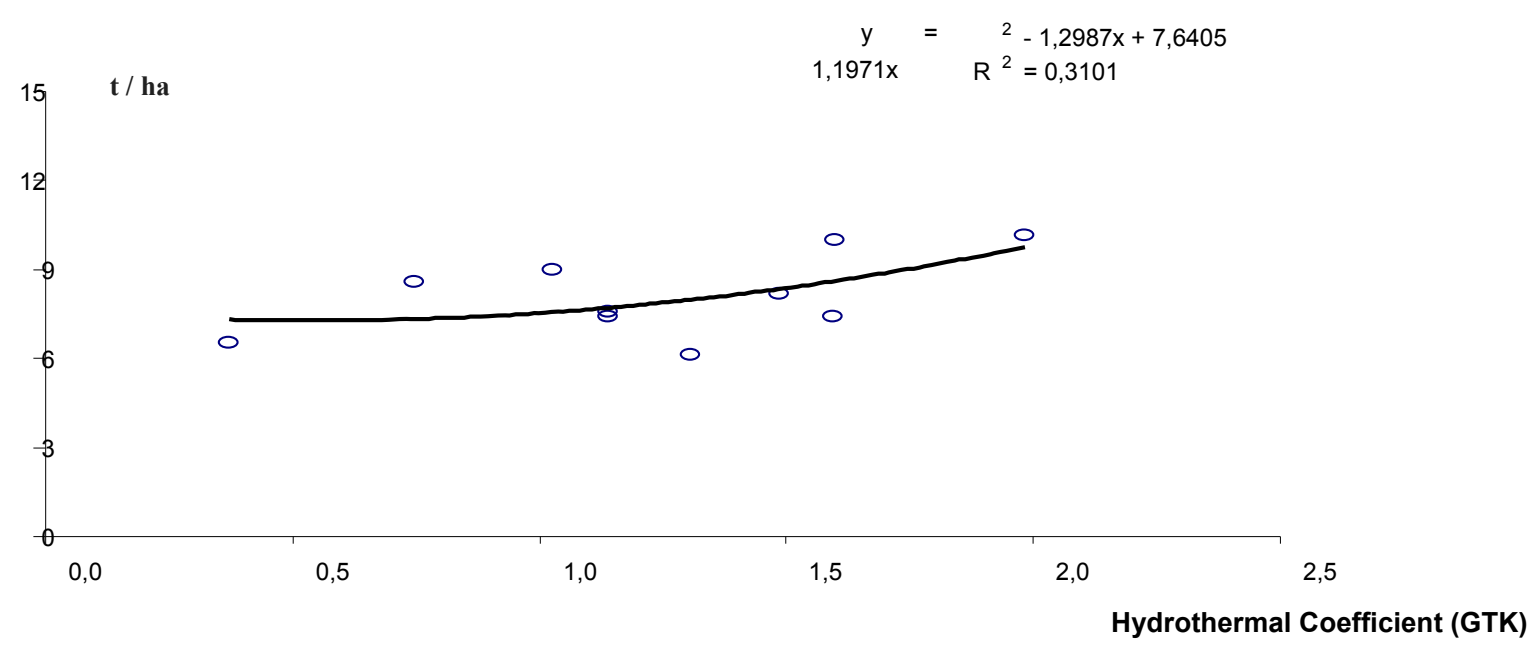

Fig. 4. Dependence of the formation of the level of productivity of the salad of the seedlings 'Snizhynka' from the hydrothermal coefficient in the conditions of the Polissya of Ukraine (20062015).

The dependence of the crop salad yield on hydrothermal coefficients of different soil-climatic zones of the Left Bank Forest-steppe and Polissya (Table 1) was also analyzed. It was established that the dependence of yield formation in the zones of the Left Bank Forest-steppe and Polissya on the coefficient of elasticity, respectively, was 0.05 and 0.26 , indicating a greater favorable conditions for the foreststeppe for the growth and development of the salad of the seedlings.

The corresponding dependence is confirmed by the value of the correlation coefficient between the parameters of yield and the hydrothermal coefficient, which for the Polissya zone $r=0.57$, whereas in the Left-Bank Forest Steppe $r=0.39$.

Table 1 Dependence of the crop yield of the sown leafy variety 'Snizhynka' from hydrothermal coefficients of the zones of the Left Bank Forest-steppe and Polissya

\begin{tabular}{|c|c|c|c|c|c|c|c|c|}
\hline \multirow{2}{*}{ Year } & \multicolumn{2}{|c|}{$\begin{array}{l}\text { Amount of active } \\
\text { temperatures, }{ }^{\circ} \mathrm{C}\end{array}$} & \multicolumn{2}{|c|}{$\begin{array}{c}\text { Amount of } \\
\text { precipitation, } \mathrm{mm}\end{array}$} & \multicolumn{2}{|c|}{ GTK (X) } & \multicolumn{2}{|c|}{$\begin{array}{l}\text { Productivity, } \mathrm{t} / \mathrm{ha} \\
\text { (fact.) }(\mathrm{Y})\end{array}$} \\
\hline & $\begin{array}{c}\text { Forest } \\
\text {-steppe }\end{array}$ & $\begin{array}{l}\text { Polis } \\
\text { sya }\end{array}$ & $\begin{array}{c}\text { Forest } \\
\text {-steppe }\end{array}$ & $\begin{array}{l}\text { Polis } \\
\text { sya }\end{array}$ & $\begin{array}{c}\text { Forest } \\
\text {-steppe }\end{array}$ & $\begin{array}{l}\text { Polis } \\
\text { sya }\end{array}$ & $\begin{array}{l}\text { Forest } \\
\text {-steppe }\end{array}$ & $\begin{array}{l}\text { Polis } \\
\text { sya }\end{array}$ \\
\hline 2006 & 1163 & 968 & 77,1 & $\begin{array}{r}154,8 \\
0\end{array}$ & 0,66 & 1,60 & 9,5 & 10,00 \\
\hline 2007 & 1260 & 1073 & 102,3 & $\begin{array}{r}122,3 \\
0\end{array}$ & 0,81 & 1,14 & 9,0 & 7,40 \\
\hline 2008 & 1076 & 947 & 110,6 & $\begin{array}{r}107,7 \\
0\end{array}$ & 1,03 & 1,14 & 12,2 & 7,60 \\
\hline 2009 & 1222 & 1031 & 87,7 & $\begin{array}{r}153,3 \\
0\end{array}$ & 0,72 & 1,49 & 11,7 & 8,20 \\
\hline 2010 & 1308 & 1226 & 62,7 & 45,80 & 0,48 & 0,37 & 11,4 & 6,53 \\
\hline 2011 & 1262 & 1102 & 123,5 & $\begin{array}{r}113,1 \\
0\end{array}$ & 0,98 & 1,03 & 11,3 & 9,00 \\
\hline 2012 & 1148 & 1010 & 56,6 & $\begin{array}{r}200,1 \\
0\end{array}$ & 0,49 & 1,98 & 8,2 & 10,17 \\
\hline 2013 & 1318 & 1222 & 83,2 & 91,40 & 0,63 & 0,75 & 8,51 & 8,60 \\
\hline
\end{tabular}




\begin{tabular}{|c|c|c|c|c|c|c|c|c|}
\hline 2014 & 1189 & 1049 & 193,5 & $\begin{array}{r}137,2 \\
0\end{array}$ & 1,63 & 1,31 & 6,8 & 6,11 \\
\hline 2015 & 1196 & 1048 & 135,0 & $\begin{array}{r}167,1 \\
0\end{array}$ & 1,13 & 1,60 & 6,7 & 7,40 \\
\hline $\begin{array}{l}\text { avera } \\
\text { ge }\end{array}$ & 1214 & 1066 & 103 & $\begin{array}{l}135,6 \\
4\end{array}$ & 0,9 & 1,30 & 9,53 & 8,10 \\
\hline $\mathrm{V}, \%$ & 6,21 & 8,42 & 39,24 & 34,08 & 40,78 & 37,12 & 21,28 & 16,77 \\
\hline \multicolumn{3}{|c|}{ Forest-steppe } & \multicolumn{6}{|c|}{$Y=-51618 x^{2}+8,3043 x+6,7707, r=0,39$} \\
\hline \multicolumn{3}{|c|}{ Polissya } & \multicolumn{6}{|c|}{$Y=1,1971 x^{2}-1,2987 x+7,6405, \quad r=0,56$} \\
\hline
\end{tabular}

The coefficient of variation in the level of yield of salad in the forest-steppe zone was $21.28 \%$, which was significantly higher than this parameter in the Polissya area, where the variability of the crop yield was $16.77 \%$. The analysis of the adaptive capacity of the seedlings 'Snizhynka' on the level of yield proved (Table 2) that the overall adaptive capacity was positive in the forest-steppe zone $(0.75)$. The specific adaptive capacity of the variety was also increased in the forest-steppe zone (3.93\%), while in the Polissya conditions this parameter was 1.67 .

Table 2 Parameters of zonal adaptability of the crop yield of salad of the seedlings 'Snizhynka' (average for 2006-2015)

\begin{tabular}{|c|c|c|c|c|c|c|}
\hline \multirow[b]{2}{*}{$\begin{array}{l}\text { Growing } \\
\text { zone }\end{array}$} & \multirow[b]{2}{*}{ 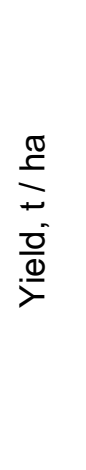 } & \multicolumn{5}{|c|}{ Parameters of zonal adaptability } \\
\hline & & 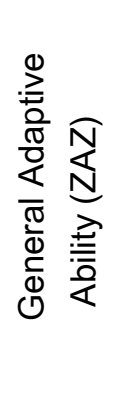 & 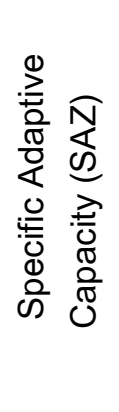 & 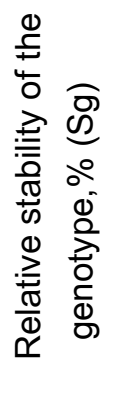 & 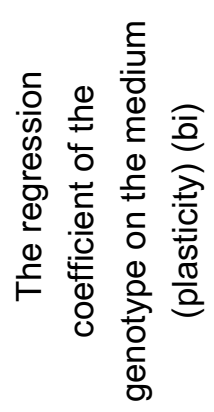 & 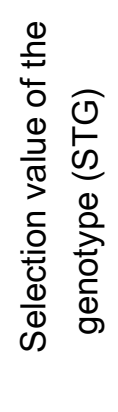 \\
\hline $\begin{array}{c}\text { Forest- } \\
\text { steppe } \\
\text { (IOB NAAN) }\end{array}$ & 9,53 & 0,75 & 3,93 & 20,24 & 1,24 & 4,13 \\
\hline $\begin{array}{l}\text { Polissya } \\
\text { (DC } \\
\text { 'Mayak') }\end{array}$ & 8,18 & $-0,75$ & 1,67 & 15,94 & 0,76 & 4,59 \\
\hline
\end{tabular}

It was determined that the relative stability of the variety is greater in the conditions of the foreststeppe $(20.24 \%)$, that is, in the data of the soil-climatic conditions for the variation of weather conditions, stable high productivity is not guaranteed. But in the conditions of the forest-steppe, the 'Snizhynka' salad was more plastic (1.24), which is, under favorable weather conditions, showed relatively high yields. In the conditions of Polissya, on the contrary, the Snowflake variety was less plastic $(0.76)$ and with a lower level of relative stability of the genotype (15.94\%). The breeding value of the genotype (STG) for the variety of sowing snowflake in the Polissya area was higher by 4.59 , whereas in the Forest-steppe 4.13.

\section{Conclusions}

In the zone of the Left Bank Forest-steppe, according to the fluctuations of the year of cultivation of the sum of active temperatures $1076-1318{ }^{\circ} \mathrm{C}$ and the amount of precipitation $56,6-193,6 \mathrm{~mm}$, the yield of salad of the sowing 'Snizhynka' variety was $6.7-12.2 \mathrm{t} /$ ha. In the Polissy area, the ratio between precipitation to the sum of active temperatures (SCC) almost did not affect the formation of yields at its fluctuation from 0.65 to 1.48 . The dependence of yield formation in the forest-steppe and Polissya zones on the coefficient of elasticity, respectively, was 0.05 and 0.26 , indicating the favorable conditions of the 
natural zone of the Left-Bank Forest-steppe for the development of lettuce. The general and specific adaptive ability of the 'Snizhynka' variety was higher in the Forest-steppe zone ( 0.75 and 3.93 respectively); the largest breeding value of the variety is characteristic for the Polissya zone (4.59).

\section{References}

1. Horovaia T. K. (1979). Sortoizuchenie salata pri razlichnykh srokakh poseva y vysadki rassady v plenochnykh teplytsakh. [Sorting salad with different periods of sowing and seedling seedlings in film greenhouses]. Nauchno-tekhn. biull. [Scientific and Technical bell]. Kharkiv: UNYYOB, № 10. P. 31-36. [in Russian].

2. Ulianych O. I., Ketskalo V.V.(2007). Zastosuvannia sortovoi tekhnolohii - neobkhidna umova pidvyshchennia urozhainosti salatu. [The use of high technology is a necessary condition for increasing the yield of lettuce]. Materialy naukovoi konferentsii. Uman, P. 76-78. [in Ukrainian].

3. Borysova R. L., Borysov V. Ya., Perehudt M. F.( 1979) Malorasprostranyonnye ovoshchnye kultury: spravochnyk.[ Few vegetable crops: a reference book]. Symferopol: Tavryia, 192 p. [in Russian].

4. Hrushko M. F.(1967) Zelenni ovochevi kul'tury. [Green vegetable crops]. K.: Urozhay, 68 p. [in Ukrainian].

5. Hrushko M. F. (1973). Zelenni ovochevi kultury. [Green vegetable crops.]. K.: Urozhai, 56 p. [in Ukrainian].

6. Gorovaya T. K., Yarovoy G. I., Guzenko T. V.(2005). Adaptivnyye parametry iskhodnykh form salata dlya selektsii stabil'nykh gibridov F1. Mezhdunarodnyy simpozium: materialy dokladov, soobshcheniy [Adaptive parameters of the original forms of lettuce for breeding stable F1 hybrids. International Symposium: materials of reports, communications ] (Moskva, 9-12 avgusta 2005 g.). Moskva:. Tom Î́. P. 135-136. [in Russian].

7. Zavadskaia O.(2007) Osobennosti vyrashchivaniya i vysadki rassady ovoshchnykh kul'tur.[Features of growing and transplanting vegetable crops.].Ovoshchevodstvo.[ Vegetable growing]. № 3. P. 36-40. [in Russian].

8. Pozniak A. V, Tkalych Yu.V, Leshchuk N.V. Raznoobrazye otechestvennoho sortymenta salata posevnoho[Variety of domestic assortment of lettuce] / Ovoshchevodstvo. - 2014. - № 7 (115). - S. 28-34. [in Russian].

9. Sych Z.D., Bobos Y.M.(2011). Ovoshch budushcheho - salat. [Vegetable of the future - lettuce] Ovoshchevodstvo. № 5. - P. 4-5. [in Russian].

10.Bondarenko H. L. Yakovenko K. I. (Eds).(2001). Metodyka doslidnoyi spravy v ovochivnytstvi i bashtannytstvi.[ Methods of experimental work in vegetable and melon]. KH. : Osnova,. 369 p. [in Ukrainian].

11.Kil'chevs'kiy A. V., Khotil'ova L. V. (1985). Otsenka adaptivnoy sposobnosti i stabil'nosti sortov i gibridov ovoshchnykh kul'tur. Metodicheskiye ukazaniya po ekologicheskomu ispytaniyu ovoshchnykh kul'tur $v$ otkrytom grunte.[ Assessment of adaptive capacity and stability of varieties and hybrids of vegetable crops. Guidelines for environmental testing of vegetable crops in open ground.]. M.,. Chast' II. P. 43-53. [in Russian].

12.Selianynov H. T. O selskokhoziaistvennoi otsenke klymatov.[ About agricultural climate assessment].. Trudy po s.-kh. meteorolohyi.[ Works on s.-h. meteorology.].. M.-L.: Selkhozghyz, T. 20. P. $120-131$.

13.Zhuchenko A. A. (1990) Adaptyvnoe rastenyevodstvo (эkoloho-henetycheskye osnovy) [Adaptive crop production (ecological and genetic basis)]. Kyshynev: Shtyyntsa, . 432 p. [in Russian].

14. Eberhart S.A. , Rassel W.A. .(1925) Stabillity parameters for comparing varieties. Crop.Science vol.6 .P.36-40/ [in english]. 